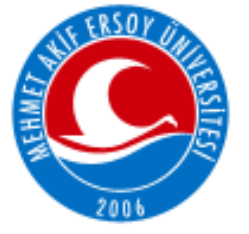

MEHMET AKIF ERSOY ÜNIVERSITESI SAĞLIK BİLIMLERİ ENSTITÜSÜ DERGISII

"MAKÜ Sag. Bil. Enst. Derg."

http://edergi.mehmetakif.edu.tr/index.php/sabed/index

\title{
Genetic characterization of Varroa destructor (Family: Varroidae) prevalent in honeybees (Apis mellifera) in the province of Aydın in
} Turkey

\author{
Aydın Bölgesindeki Bal Arllarında (Apis mellifera) Bulunan Varroa \\ destructor'un (Akar: Varroidae) Genetik Karakterizasyonu
}

\author{
Adnan Ayan', Osman Selçuk Aldemir ${ }^{2}$ \\ ${ }^{1}$ Van Yüzüncü Y1l University, Faculty of Veterinary, Department of Genetics, Van, TURKEY \\ ${ }^{2}$ Adnan MenderesUniversity, Faculty of Veterinary, Department of Parasitology, Aydın, TURKEY
}

\begin{abstract}
The aim of the present study was to identify the haplotypes of the Varroa destructor mite which infects honeybees (Apis mellifera) in the province of Aydin in Turkey, using two different modified techniques for the mitochondrial Cox1 gene of the mite. In order to confirm the haplotype, two different primer pairs were selected. 376 bp DNA in size was amplified using the first primer pair. SacI restriction enzyme was applied to the amplified products; however, this restriction enzyme did not cut the DNA. 570 bp DNA in size was amplified using the second primer pair. XhoI and SacI restriction enzymes were used for the amplified products. Although, the SacI restriction enzyme did not cut the DNA, the XhoI restriction enzyme cut the amplified DNA into two fragments (bands), with the sizes of 270 and 300 bp two bands 270 and $300 \mathrm{bp}$. While comparing the results, these bands were found specific for Korean haplotype of $V$. destructor. In conclusion, all of the 200 samples of $V$. destructor examined in this study were identified to be the Korean haplotype.
\end{abstract}

Key words: Varroa destructor, Genetic characterization, Aydın

Contact Information: Assistant Professor Adnan Ayan, Van Yüzüncü Yıl University, Faculty of Veterinary, Department of Genetics, Van, TURKEY

E-mail: adnanayan@yyu.edu.tr

Phone: +90 432 2251128 / 21549

How to cite this paper: Ayan A, Aldemir OS. 2018. Genetic characterization of Varroa destructor (Family: Varroidae) prevalent in honeybees (Apis mellifera) in the province of Aydin in Turkey. MAKU Journal of Health Sciences Institue. 6(1): 26-32.

doi: $10.24998 /$ maeusabed.435383
Öz: Bu çalışmada; Aydın bölgesinde bal arılarında (Apis mellifera) görülen Varroa destructor'un mitokondriyal Cox1 geninin haplotiplerinin belirlenmesi amacıyla farklı iki teknik modifiye edilerek uygulanmıştır. Haplotip belirlenmesi amacıyla iki farklı primer çifti seçilmiştir. Birinci primer çiftiyle 376 bp büyüklüğünde DNA amplifiye edilmiştir. Amplifiye ürüne SacI restriksiyon enzimi uygulanmış ancak bu restriksiyon enziminin DNA'yı kesmediği görülmüştür. İkinci primer çiftiyle 570 bp büyüklüğünde amplifiye DNA elde edilmiştir. Elde edilen amplifiye DNA'ya XhoI restriksiyon enzimi ve $S a c$ I restriksiyon enzimleri uygulanmıştır. Ancak SacI restriksiyon enziminin DNA'y1 kesmediği, XhoI restriksiyon enziminin ise elde edilen genomik DNA amplifikasyonunda 270 ve 300 bp büyüklüğünde iki band oluşturduğu saptanmıştır. Sonuçlar karşılaştırıldığında; elde edilen bandların V. destructor Kore haplotipi için spesifik olduğu tespit edilmiştir. Sonuç olarak; $V$. destructor'un haplotipinin belirlenmesine yönelik yapilan bu araştırmada, incelenen 200 örneğin tamamının V. destructor Kore haplotipi olduğu saptanmıştır.

\begin{tabular}{lll}
\hline Anahtar sözcükler: & Varroa destructor, Genetik \\
karakterizasyon, Aydın & & \\
\hline
\end{tabular}

Received: 21.06.2018 Accepted: 13.07.2018 
Genetic characterization of Varroa destructor (Family: Varroidae) prevalent in honeybees (Apis mellifera) in the province of Aydin in Turkey

Aydın Bölgesindeki Bal Arılarında (Apis mellifera) Bulunan Varroa destructor'un (Akar: Varroidae) Genetik Karakterizasyonu

\section{Introduction}

Honeybee health is an important topic in beekeeping by reason of Apis mellifera play an critical role in the pollination of agricultural crops (Ghazoul, 2005; Melin et al., 2014). Honeybees contribute to biodiversity conservation and food security. Honeybees provide source of income to beekeepers by sale of hive products (Jacobs et al., 2006). Varroa destructor is right now considered the largest threat to beekeeping worldwide and cause more damage, higher economic costs than all other known apicultural diseases (Boecking and Genersch, 2008). This mite is common all over the World (Dietemann et al., 2013; Fazier et al., 2010; Muli et al., 2014; Strauss et al., 2013) V. destructor is a factor for colony collapses in Europe and North America (Dainat et al., 2012; Shen et al., 2005). This mites suck the honeybee colonies hemolymph also weakens the honeybee colonies (Rosenkranz et al., 2010) it also acts as a vector for several viruses and spreads colonies (Amdam et al., 2004) especially $V$. destructor Korean and Japanese haplotypes were capable to infest A. mellifera populations (Anderson and Trueman, 2000). The Japanese haplotypes is seen low infestation levels in South and Central America, but the Korean haplotype is found high infestation levels in Europe (Strapazzon et al., 2009) Intensive beekeeping activities in Aydin region cause Varroosis problems and significant economic losses. For this reason, it is aimed to investigate the genetic characterization of $V$. destructor in Aydin region using molecular techniques.

\section{Material and Methods}

In this study, 200 adult female $V$. destructor mites were collected from queen bees, male bees and worker bees from the hives of the beekeeping enterprises in Aydin region from September 2014 to September 2015. The study protocol was reviewed and approved by the Animal Care and Use Committee of Adnan Menderes University (Number: 64583101/2014/177).

Therefore, especially Bozdoğan, Buharkent, Çine, Didim, Merkez, Germencik, İncirliova, Karacasu, Karpuzlu, Köşk, Kuşadası, Kuyucak, Nazilli, Paşayaylası, Söke, Sultanhisar, Yenipazar districts, which are rich in terms of apiculture, were preferred. The collected samples were kept at $-20^{\circ} \mathrm{C}$ until they were brought to the laboratory. The $V$. destructor samples brought to the laboratory were subjected to DNA extraction using the format (Qiagen DNeasy Blood \& Tissue Kit, 69504) as reported in the literature (Dietemann 
Genetic characterization of Varroa destructor (Family: Varroidae) prevalent in honeybees (Apis mellifera) in the province of Aydin in Turkey

Aydın Bölgesindeki Bal Arılarında (Apis mellifera) Bulunan Varroa destructor'un (Akar: Varroidae) Genetik Karakterizasyonu

et al., 2013). A randomly selected sample haplotype from beekeeping establishments was identified and used as the positive control. The positive control PCR product to be sequenced was sent to a special company for the purpose of synthesizing. In the total $50 \mu \mathrm{L}$ reaction; 5 $\mu \mathrm{L}$ 10X PCR Buffer (Geneaid, New Taipei City, Taiwan), 3 mM MgCl 2 (Geneaid, New Taipei City, Taiwan), and $50 \mu \mathrm{L}$ DNase / RNase-Free Distilled Water (Gibco Thermo Fisher Scientific, Waltham, MA USA), $1.5 \mu \mathrm{L}$ Reverse primer (Iontek, Istanbul, Turkey), 1.25 units of Taq DNA polymerase (Geneaid, New Taipei City, Taiwan), 1 mM dNTP (Geneaid, New Taipei City, Taiwan) and 16 ng of DNA sample were used.

Two primers with different sequences were used for the amplification of the Cox 1 gene of $V$. destructor. 5'-TACAAAGAGGGAAGAAGCAGCC-3' Forward and 5'GCCCCTATTCTTAATACATAGTGAAAATG-3' Reverse primers (Solignac et al., 2005) and COXF [5'GG(A/G)GG(A/T)GA(C/T)CC(A/T)ATT(C/T)T(A/T)TATCAAC3'] Forward and COXRa [5'GG(A/T)GACCTGT(A/TA(A/T)AATAGCAAATAC3'] Reverse primers (Strapazzon et al., 2009) were synthesized at a commercial company. The reaction was carried out on an AB Applied Biosystems Veriti automated thermal cycler. The steps of the reaction are as follows: preliminary denaturation at $94^{\circ} \mathrm{C}$ for $4 \mathrm{~min}$, denaturation in each of the cycles at $94^{\circ} \mathrm{C}$ for $1 \mathrm{~min}$, annealing at $50^{\circ} \mathrm{C}$ for $1.30 \mathrm{~min}$, elongation at $72^{\circ} \mathrm{C}$ for $1.30 \mathrm{~min}$ and the last elongation phase consisting of 35 cycles at $72^{\circ} \mathrm{C}$ for 10 minutes. Then, $1.5 \%$ agarose gel was prepared. The PCR products in the agarose gel were subjected to electrophoresis for 1 hour in a 90-volt linear current. After this process, "UV transilluminator, UVP EC3 ChemiHR 410 Imaging System" images were obtained in the gel imaging device. The resulting bands were evaluated by their comparison with DNA markers. V. destructor was used to identify the Japanese and Korean haplotypes using the SacI restriction enzyme with recognition points 5'...GAGCTC...3' 3'...CTCGAG...5' and the XhoI digestion enzyme 5'...GTCGAG...3' 3'...GAGCTC...5' as described in the study of Anderson and Fuchs (1998). R0156S-0501212 New England Biolabs SacI restriction enzyme and R0146S0581507 New England Biolabs XhoI restriction enzyme were used, and 2\% agarose gel images were obtained. 
Genetic characterization of Varroa destructor (Family: Varroidae) prevalent in honeybees (Apis mellifera) in the province of Aydin in Turkey

Aydın Bölgesindeki Bal Arılarında (Apis mellifera) Bulunan Varroa destructor'un (Akar: Varroidae) Genetik Karakterizasyonu

\section{Results}

The genomic DNA amplifications obtained using different primers and different methods are presented in Figure 1-4.

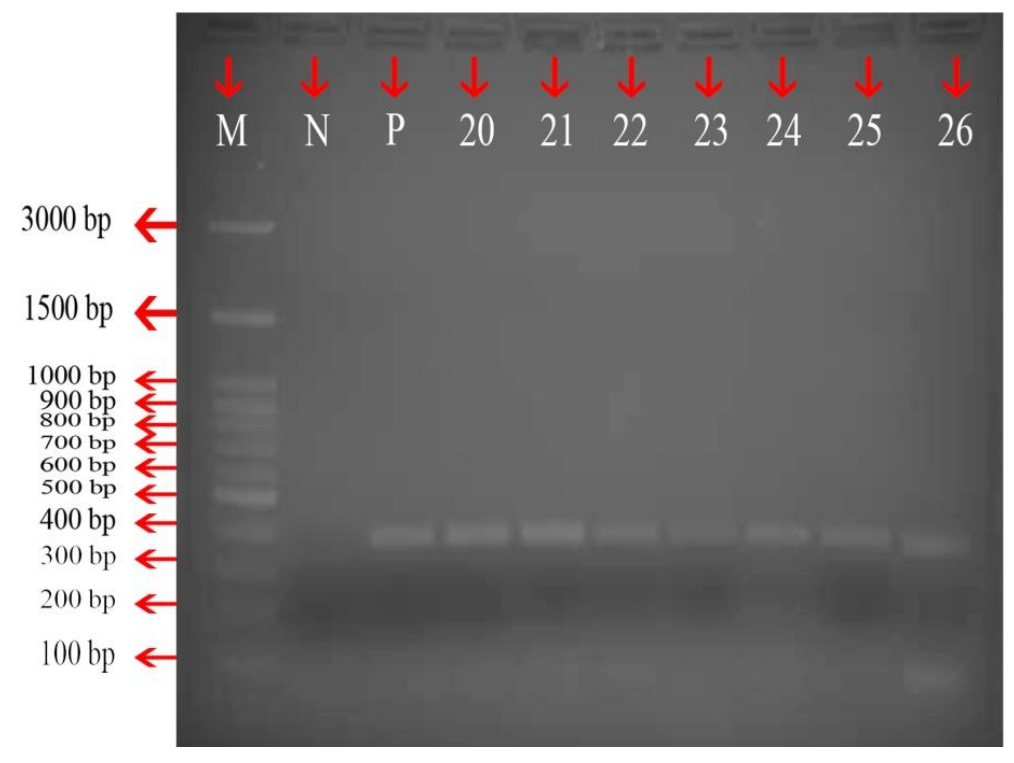

Figure 1. Varroa destructor Cox 1 gene region of mtDNA $1.5 \%$ gel electrophoresis image of some of the samples in the PCR process (approximately $376 \mathrm{bp}$ )

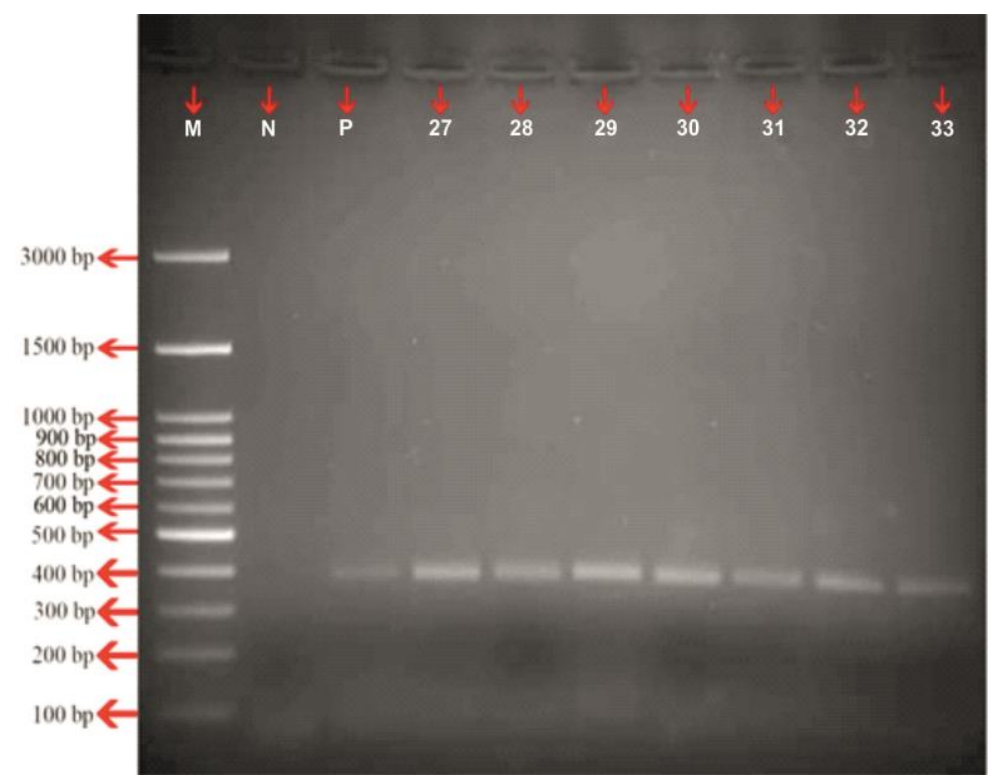

Figure 2. Varroa destructor restriction profiles of Cox1 region of mtDNA was digested with endonucleases SacI (S) $2 \%$ Gel electrophoresis image of the samples in the Restriction fragment length polymorphism (RFLP) process 
Genetic characterization of Varroa destructor (Family: Varroidae) prevalent in honeybees (Apis mellifera) in the province of Aydin in Turkey

Aydın Bölgesindeki Bal Arılarında (Apis mellifera) Bulunan Varroa destructor'un (Akar: Varroidae) Genetik Karakterizasyonu

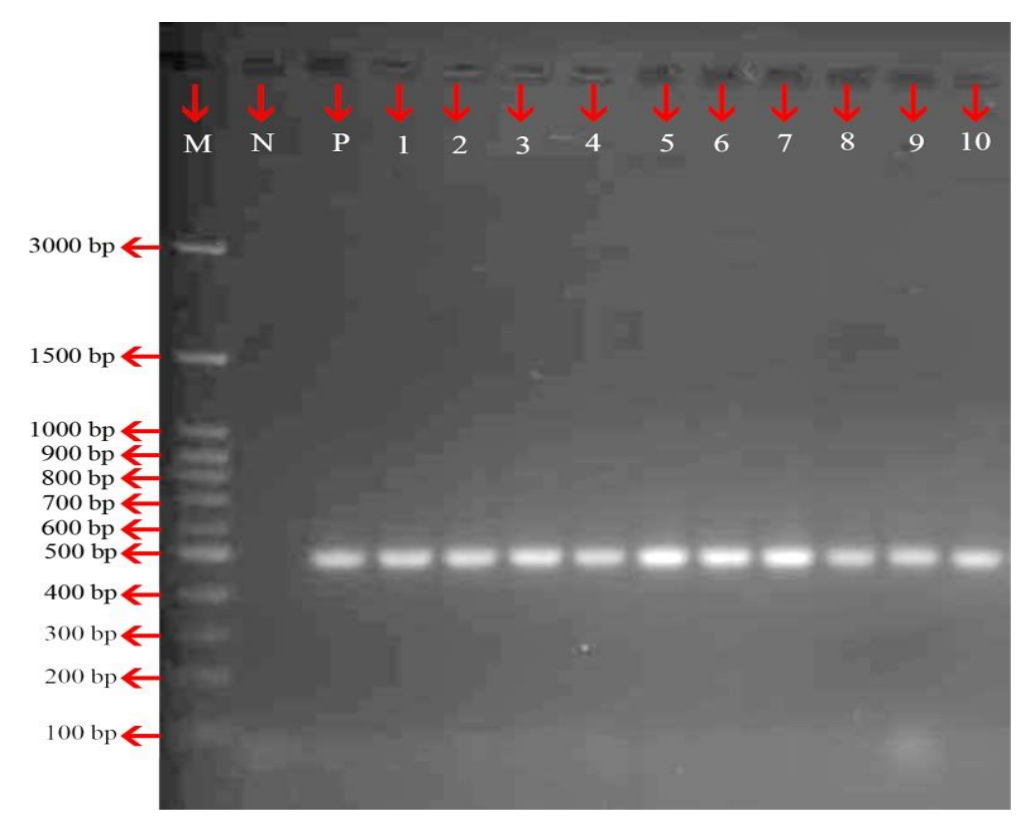

Figure 3. Varroa destructor Cox 1 gene region of mtDNA $1.5 \%$ gel electrophoresis image of some of the samples PCR process (approximately $570 \mathrm{bp}$ )

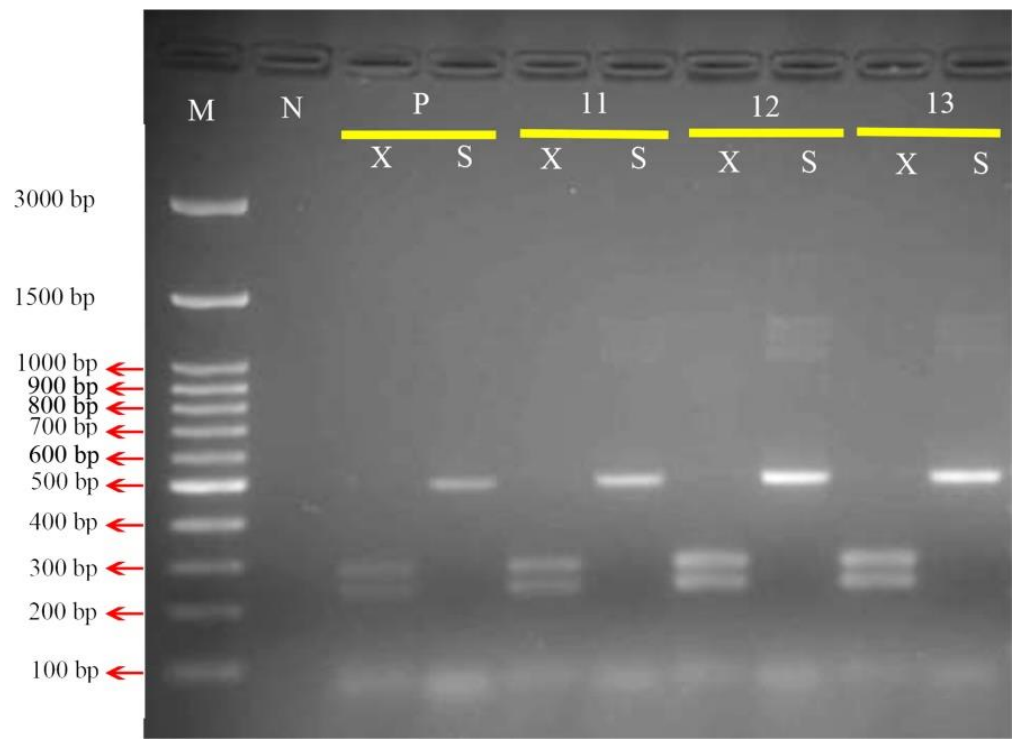

Figure 4. Varroa destructor restriction profles of Cox 1 region of mtDNA was digested with endonucleases $\mathrm{SacI}(\mathrm{S})$ ve XhoI (X) 2\% Gel electrophoresis image of the samples in the Restriction fragment length polymorphism (RFLP) process 
Genetic characterization of Varroa destructor (Family: Varroidae) prevalent in honeybees (Apis mellifera) in the province of Aydin in Turkey

Aydın Bölgesindeki Bal Arılarında (Apis mellifera) Bulunan Varroa destructor'un (Akar: Varroidae) Genetik Karakterizasyonu

In Figure 1 Solignac et al. (2005) primers were used, and a 376 bp band was amplified for the $V$. destructor Cox 1 gene findings in the 200 samples examined. The amplified $376 \mathrm{bp}$ band is specific for $V$. destructor. In Figure 2, the amplified band $376 \mathrm{bp}$ in size in the genomic DNA amplification obtained using the SacI restriction enzyme is specific for $V$. destructor and forms $V$. destructor Korean haplotype.

In Figure 3 Strapazzon et al. (2009) primers were used, and a 570 bp band was amplified for the $V$. destructor Cox 1 gene findings in the 200 samples examined. The amplified $570 \mathrm{bp}$ band is specific for V. destructor. In Figure 4, the SacI and XhoI restriction enzymes were used, but only the XhoI restriction enzyme cut the amplified genomic DNA. The SacI restriction enzyme did not cut the amplified genomic DNA. In the genomic DNA amplification obtained using the XhoI restriction enzyme, two bands 270 and $300 \mathrm{bp}$ in size were acquired. The obtained bands are specific for $V$. destructor Korean haplotype.

According to these results, when considering the band numbers and sizes obtained in the study conducted for the genetic characterization of $V$. destructor, it has been observed that all of the 200 samples examined are $V$. destructor Korean haplotype and in none of the samples, the Japanese haplotype has been detected.

\section{Discussion}

$V$. destructor is an invader species and rapidly spread in A. mellifera colonies, having a great impact across the globe. Different Varroa genotypes appear to be important agents in the population aliveness of the $V$. destructor (De Guzman et al., 1998; Strapazzon et al., 2009). In many parts of the world (Akinwande et al., 2012; Ayan et al., 2017a; Ayan et al., 2017b; Beaurepaire et al., 2015; Chemurot et al., 2016; Fazier et al., 2010 Gajic et al., 2013; Maggi et al., 2012; Muñoz et al., 2008; Navajas et al., 2010; Rasolofoarivao et al., 2013; Solignac et al., 2005; Strapazzon et al., 2009; Warrit et al., 2004), studies have been carried out to determine which haplotypes Varroa destructor has.

Beaurepaire et al. (2015) have found that the $V$. destructor obtained from Apis mellifera in the cities of Lipa, Dien Bien and Son La is the Korean haplotype. Chemurot et al. (2016) have determined V. destructor South Korean haplotypes with sequence results in Uganda. Fazier et al. (2010) have found Korean haplotype in honeybee colonies likely $A$. mellifera scutellata, and possibly A. mellifera scutellata hybrids Kenya. Akinwande et al. (2012) have found that $V$. destructor is the Korean haplotype in A. mellifera colonies in 
Genetic characterization of Varroa destructor (Family: Varroidae) prevalent in honeybees (Apis mellifera) in the province of Aydin in Turkey

Aydın Bölgesindeki Bal Arılarında (Apis mellifera) Bulunan Varroa destructor'un (Akar: Varroidae) Genetik Karakterizasyonu

southwest Nigeria. Gajic et al. (2013) have found Korean haplotypes, Serbia 1 haplotypes, Peshter 1 haplotypes in Serbia. Maggi et al. (2012) have determined V. destructor Korean haplotypes in Argentina. Muñoz et al. (2008) have found V. destructor Korean haplotype and Japanese haplotype in Guadalajara city of Spain while Portugal, the Balearic island and Canary island have been found $V$. destructor Korean haplotype.

Warrit et al. (2004) have examined $V$. destructor mites from Black Sea province of Turkey. All samples have been reported to be the Korean haplotype. Ayan et al. (2017a) reported $V$. destructor Korean haplotypes in A. mellifera in the province of Van in Turkey province of Van. Ayan et al. (2017b) have found $V$. destructor Korean haplotypes in $A$. mellifera in in Siirt city of Turkey.

In this study, the Korean haplotype of $V$. destructor has been found but Japanese haplotype has not been found in Aydin province of Turkey. The results may help to develope new control strategies in Aydın

\section{References}

1. Akinwande, K.L., Badejo, M.A., Ogbogu, S.S., 2012. Incidence of the Korean haplotype of Varroa destructor in southwest Nigeria. Journal of Apicultural Research 51(4), 369-370.

2. Amdam, G.V., Hartfelder, K., Norberg, K., Hagen, A., Omholt, SW., 2004. Altered Physiology in Worker Honey Bees (Hymenoptera: Apidae) Infested with the Mite Varroa destructor (Acari: Varroidae): A Factor in Colony Loss During Overwintering?. Journal of Economic Entomology 97(3), 741-747.

3. Anderson, D.L., Fuchs, S., 1998. Two genetically distinct populations of Varroa jacobsoni with contrasting reproductive abilities on Apis mellifera. Journal of Apicultural Research 37(2), 69-78.

4. Anderson, D.L., Trueman, J.W.H., 2000. Varroa jacobsoni (Acari: Varroidae) is more than one species. Experimental and Applied Acarology 24, 165-189.

5. Ayan, A., Ural, K., Aldemir, O.S., Tutun, H., 2017a. Van Bölgesindeki Bal Arılarında (Apis mellifera) Görünen Varroa destructor'un Genetik Karakterizasyonunun Belirlenmesi Mehmet Akif Ersoy Üniversitesi Sağlık Bilimleri Enstitüsü Dergisi 5(2), 78-84.
6. Ayan, A., Aldemir, O.S., Selamoglu, Z., 2017 b. Analysis of COI Gene Region of Varroa destructor in Honey Bees (Apis mellifera) in Province of Siirt. Turkish Journal of Veterinary Research 1(1), 20-23.

7. Beaurepaire, A.L., Truong, T.A., Fajardo, A.C., , Dinh, T.Q., Cervancia, C., Moritz, R.F., 2015. Host Specificity in the Honeybee Parasitic Mite, Varroa spp. in Apis mellifera and Apis cerana. PLoS ONE 10(8), 1-12.

8. Boecking, O., Genersch, E., 2008. Varroosis the ongoing crisis in bee keeping. Journal für Verbraucherschutz und Lebensmittelsicherheit 3(2), 221-228.

9. Chemurot, M., Akol, A.M., Masembe, C., de Smet, L., Descamps, T., de Graaf, D.C., 2016. Factors influencing the prevalence and infestation levels of Varroa destructor in honeybee colonies in two highland agroecological zones of Uganda. Experimental and Applied Acarology 68(4), 497-508.

10. Dainat, B., Evans, J.D., Chen, Y.P., Gauthier, L., Neumann, P., 2012. Dead or alive: deformed wing virus and Varroa destructor reduce the life span of winter honeybees. Applied and Environmental Microbiology 78(4), 981-987. 
Genetic characterization of Varroa destructor (Family: Varroidae) prevalent in honeybees (Apis mellifera) in the province of Aydin in Turkey

Aydın Bölgesindeki Bal Arılarında (Apis mellifera) Bulunan Varroa destructor'un (Akar: Varroidae) Genetik Karakterizasyonu

11. De Guzman, L., Rinderer, T.E., Stelzer, J.A., Anderson, D., 1998. Congruence of RAPD and mitochondrial DNA markers in assessing Varroa jacobsoni genotypes. Journal of Apicultural Research 37, 49-51.

12. Dietemann, V., Nazzi, F., Martin, S.J., Anderson, D.L., Locke, B., Delaplane, K.S., Ellis, J.D., 2013. Standard methods for Varroa research. Journal of Apicultural Research 52(1), 1-54.

13. Fazier, M., Muli, E., Conklin, T., Schmehl, D., Torto, B., Frazier, J., Tumlinson, J., Evans J.D., Raina S., 2010. A scientific note on Varroa destructor found in East Africa; threat or opportunity?. Apidologie 41, 463-465.

14. Gajic, B., Radulovic, Z., Stevanovic, J., Kulisic, Z., Vucicevic, M., Simeunovic, P., Stanimirovicve, Z., 2013. Variability of the honey bee mite Varroa destructor in Serbia, based on mtDNA analysis. Experimental and Applied Acarology 61, 97-105.

15. Ghazoul, J., 2005. Buzziness as usual? Questioning the global pollination crisis. Trends in Ecology \& Evolution 20(7), 367-373.

16. Jacobs, F.J., Simoens, C., DeGraaf, D.C., Deckers, J., 2006. Scope for non-wood forest products income generation from rehabilitation areas: focus on beekeeping. Journal of the Drylands 1(2),171-185.

17. Maggi, M., Medici, S., Quintana, S., Ruffinengo, S., Marca'ngeli, J., Gimenez Martinez, P., Fuselli, S., Eguarasve, M., 2012. Genetic structure of Varroa destructor populations infesting Apis mellifera colonies in Argentina. Experimental and Applied Acarology 56, 309318.

18. Melin, A., Rouget, M., Midgley, J.J., Donaldson, J.S., 2014. Pollination ecosystem services in South African agricultural systems. South African Journal of Science 110(11), 1-9.

19. Muli, E., Patch, H., Frazier, M., Frazier, J., Torto, B., Baumgarten, T., Grozinger, C., 2014. Evaluation of the distribution and impacts of parasites, pathogens, and pesticides on honey bee (Apis mellifera) populations in East Africa. PLoS One 9(4), 1-11.

20. Muñoz, I., Garrido-Bailón, E., MartínHernández, R., Meana, A., Higes, M., De la Rúa, P., 2008. Genetic profile of Varroa destructor infesting Apis mellifera iberiensis colonies.
Journal of Apicultural Research Bee World 47, 310-313.

21. Navajas, M., Anderson, D.L., De Guzman, L.I., Huang, Z.Y., Clement, J., Zhou, T., Le Conte, Y., 2010. New Asian types of Varroa destructor. a potential new threat for World apiculture Apidologie 41, 181-193.

22. Rasolofoarivao, H., Clemencet, J., Ravaomanarivo, L.H., Razafindrazaka, D., Reynaud, B., Delatte, H., 2013. Spread and strain determination of Varroa destructor (Acari: Varroidae) in Madagascar since its first report in 2010. Experimental and Applied Acarology 60, 521-530.

23. Rosenkranz, P., Aumeier, P., Ziegelmann, B., 2010. Biology and control of Varroa destructor. Journal of Invertebrate Pathology 103, 96-119.

24. Shen, M., Yang, X., Cox-foster, D., Cui, L., 2005. The role of Varroa mites in infections of Kashmir bee virüs (KBV) and deformed wing virus (DWV) in honey bees. Virology 342, 141149.

25. Solignac, M., Cornuet, J.M., Vautrin, D., Le Conte, Y., Anderson, D., Evans, J., Cros-Arteil, S., Navajas, M., 2005. The invasive Korea and Japan types of Varroa destructor, ectoparasitic mites of the Western honey bee (Apis mellifera), are two partly isolated clones Proceedings of the Royal Society of London. Series B, Biological sciences 272, 411-419.

26. Strapazzon, R., Carneiro, F.E., Guerra Jr, J.C.V., Moretto, G., 2009. Genetic characterization of the mite Varroa destructor (Acari: Varroidae) collected from honey bees Apis mellifera (Hymenoptera, Apidae) in the State of Santa Catarina, Brazil. Genetics and Molecular Research 8(3), 990-997.

27. Strauss, U., Human, H., Gauthier, L., Crewe, R.M., Dietemann, V., Pirk, C.W.W., 2013. Seasonal prevalence of pathogens and parasites in the savannah honeybee (Apis mellifera scutellata). Journal of Invertebrate Pathology 114, 45-52.

28. Warrit, N., Hagen, T.A.R., Smith, D.R., Çakmak, I., 2004. Survey of Varroa destructor strains on Apis mellifera in Turkey. Journal of Apicultural Research 43(4), 190-191. 